The International Journal of

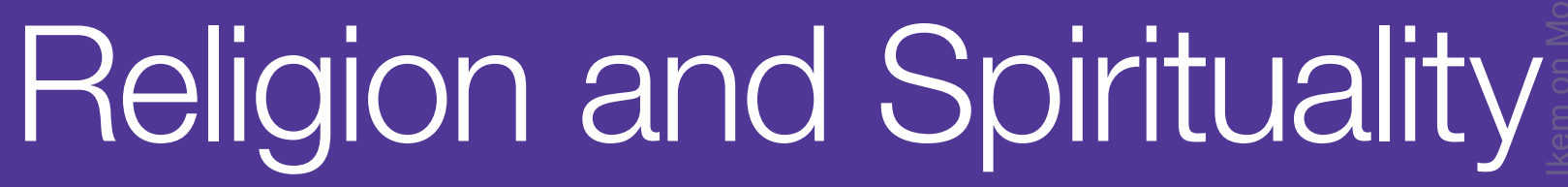

in Society

The Spirituality Approach to Electoral Politics in Africa

Evidence from the Presidential Elections in Nigeria's Fourth Republic 


\section{EDITOR}

Luis G. Roger-Castillo, University of Granada, Spain

\section{MANAGING EDITOR}

Megan Donnan, Common Ground Research Networks, USA

\section{ADVISORY BOARD}

The Advisory Board of the Religion in Society Research Network recognizes the contribution of many in the evolution of the Research Network. The principal role of the Advisory Board has been, and is, to drive the overall intellectual direction of the Research Network. A full list of members can be found at

https://religioninsociety.com/about/advisory-board.

\section{PEER REVIEW}

Articles published in The International Journal of Religion and Spirituality in Society are peer reviewed using a two-way anonymous peer review model. Reviewers are active participants of the Religion in Society Research Network or a thematically related Research Network. The publisher, editors, reviewers, and authors all agree upon the following standards of expected ethical behavior, which are based on the Committee on Publication Ethics (COPE) Core Practices. More information can be found at https://cgnetworks.org/journals/publication-ethics.

\section{ARTICLE SUBMISSION}

The International Journal of Religion and Spirituality in Society publishes biannually (June, December). To find out more about the submission process, please visit

\section{THE INTERNATIONAL JOURNAL OF RELIGION AND} SPIRITUALITY IN SOCIETY

https://religioninsociety.com

ISSN: 2154-8633 (Print)

ISSN: 2154-8641 (Online)

https://doi.org/10.18848/2154-8633/CGP (Journal)

First published by Common Ground Research Networks in 2021

University of Illinois Research Park

60 Hazelwood Drive

Champaign, IL 61820 USA

$\mathrm{Ph}:+1-217-328-0405$

https://cgnetworks.org

The International Journal of Religion and Spirituality in Society is a peer-reviewed, scholarly journal.

\section{COPYRIGHT}

(C) 2021 (individual papers), the author(s)

(C) 2021 (selection and editorial matter),

Common Ground Research Networks

All rights reserved. Apart from fair dealing for the purposes of study, research, criticism, or review, as permitted under the applicable copyright legislation, no part of this work may be reproduced by any process without written permission from the publisher. For permissions and other inquiries, please contact cgscholar.com/cg_support.

\section{Crossref}

Common Ground Research Networks, a member of Crossref

\section{ABSTRACTING AND INDEXING}

For a full list of databases in which this journal is indexed, please visit https://religioninsociety.com/journal.

\section{RESEARCH NETWORK MEMBERSHIP}

Authors in The International Journal of Religion and Spirituality in Society are members of the Religion in Society Research Network or a thematically related Research Network. Members receive access to journal content. To find out more, visit

https://religioninsociety.com/about/become-a-member.

\section{SUBSCRIPTIONS}

The International Journal of Religion and Spirituality in Society is available in electronic and print formats. Subscribe to gain access to content from the current year and the entire backlist. Contact us at cgscholar.com/cg_support.

\section{ORDERING}

Single articles and issues are available from the journal bookstore at https://cgscholar.com/bookstore.

\section{OPEN RESEARCH}

The International Journal of Religion and Spirituality in Society is Hybrid Open Access, meaning authors can choose to make their articles open access. This allows their work to reach an even wider audience, broadening the dissemination of their research. To find out more, please visit https://cgnetworks.org/journals/open-research.

\section{DISCLAIMER}

The authors, editors, and publisher will not accept any legal responsibility for any errors or omissions that may have been made in this publication. The publisher makes no warranty, express or implied, with respect to the material contained herein. 


\title{
The Spirituality Approach to Electoral Politics in Africa: Evidence from the Presidential Elections in Nigeria's Fourth Republic
}

\author{
Patrick Afamefune Ikem, University of Nigeria, Nsukka, Nigeria \\ Abiodun Omotayo Oladejo, University of South Africa, South Africa \\ Kingsley Chigozie Udegbunam, ${ }^{1}$ University of Nigeria, Nsukka, Nigeria
}

\begin{abstract}
Extant literature is replete with studies on electoral process in Africa and, in particular, Nigeria. However, there is dearth of scholarly interest in interrogating the import of spiritualization of politics in Africa's body politic. Regardless of the scant attention given to this phenomenon in research, it is increasingly becoming a recurring decimal in the electoral cycles of some Africa countries. Using the Nigerian presidential elections as the unit of analysis for this article, we highlight the need for attention to be reasonably focused on the potentials inherent in spiritualization of politics. The article specifically looks at how divine predictions and prophecies about winners or losers by some religious leaders or acclaimed spiritualists at every round of election in Nigeria are fast becoming integral aspects of Nigerian politics. These spiritual modes to politics, the article argues, may assume threatening dimensions because of their capability to undermine state institutions such as the Independent National Electoral Commission (INEC) and security agencies during election periods. Therefore, this article recommends that fledgling democracies such as Nigeria's need to put machinery in place to protect their electoral systems and related institutions from threats inherent in unguarded electoral predictions by religious leaders and spiritualists.
\end{abstract}

Keywords: Electoral Prophecies, Presidential Elections, Politicization, Pentecostals and Polls

\section{Introduction}

$\mathrm{S}$ cholars of African studies have written extensively about the imperative of strengthening democratic tenets and norms as a post-transition paradigm shift (Omenma 2019). This concern looks at the institutional and procedural processes required to guarantee the sustenance of democracy. Notably, the conduct of free and fair elections is one of the requirements for entrenching democracy. While several studies have been done on election and electioneering process in Africa, there appears to be lack of adequate recognition of the copious manifestations of spiritual dimension to politics in Africa by scholars of democracy and democratization process in Africa. This is despite the strong tie that binds religion and politics in Africa (Ayantayo 2009; Burgess 2015). The phenomenon of spiritualizing electoral politics implies subscribing to the idea that winning election is not only dependent on political sagacity but also some supernatural assistance (Ayantayo 2009). The electoral outcome is dependent on the predetermined influence of supernatural forces whose intervention and/or help is capable of favorably swaying the electorate in the direction of a particular candidate or political party. Studies in politics and psephology have regrettably neglected to analyze the spiritual dimension of Africa's electoral system. Even though it has become an element in the democratization process on the continent, it is yet to be recognized as an important nuance that impinges on the electoral process. This neglect may not be unconnected with the predominant Eurocentric bias in the social sciences built upon scientific methodology which would look at politics as an objective reality not underpinned by subjectivism and non-scientific modes of explanation.

\footnotetext{
${ }^{1}$ Corresponding author: Kingsley Chigozie Udegbunam, Peace and Conflict Resolution Unit, School of General Studies, University of Nigeria, Nsukka. kingsley.udegbunam@unn.edu.ng
}

The International Journal of Religion and Spirituality in Society

Volume 12, Issue 1, 2021, https://religioninsociety.com

(C) Common Ground Research Networks, Patrick Afamefune Ikem,

Abiodun Omotayo Oladejo, Kingsley Chigozie Udegbunam All Rights Reserved.

Permissions: cgscholar.com/cg_support

ISSN: 2154-8633 (Print), ISSN: 2154-8641 (Online)

https://doi.org/10.18848/2154-8633/CGP/v12i01/33-52 (Article) 
However, scholars like Ayantayo (2009), N'Guessan (2015), Heuser (2015), Gez and Droz (2015), Burgess (2015), Yong (2014), Acheampong (2018), among others, have made significant contributions to the discourse on the spiritual dimensions and manifestations in politics and the electoral process in some African countries. For instance, Acheampong (2018) argues that the politically active engagements of Pentecostals in Ghana have culminated into a shift to the theology of spiritual causality, which is at the root of the development of a distinctive brand of prophetic politics generally referred to as "divining." Similarly, in Nigeria, the Pentecostals" involvement in elections cuts across a gamut of interventions namely endorsement of candidates, campaigning for candidates and prophesying their victories. It is almost a rarity for elections to be conducted in Nigeria without the public sphere being inundated with electoral prophecies and predictions by acclaimed religious leaders and spiritualists.

This culture of prophetism during election sharply contrasts with what is obtainable in most developed democracies where surveys and polls are used to predict election outcomes. The United States of America is one country where the culture of electoral forecasting using surveys and polls is ingrained. The precursor to this was the eighteenth century's practice of sampling public opinion on issues bordering on the economy, politics and social development. However, the first electoral forecast - scientific - took place in the 1930s (Rothschild and Wolfers 2012). Even though it was very limited in scope, it marked the first empirical basis for polling public opinion on political parties, candidates and critical national issues. Professional polls and surveys have since become integral aspects of US electioneering process. However, it must be mentioned that election forecast based on professional polls and surveys has been found to have its inadequacies because of differing levels of accuracy and possible bias of pollsters. That said, there is no gainsaying the utility of these techniques in countries where they are used, especially as they have, more often than, proved heuristic.

In an evolving democracy like Nigeria, election forecast based on pre-election surveys and pulse-feeling of the electorate has not gained wide acceptance. This is not unconnected with poor attitude toward scientific data-devoid of bias - and the usual politicization of issues (Sobechi 2016). These are further exacerbated by the prevalence of primordial attachments and affiliation such as ethnicity and religion. Campaigns and preparation for election that should be underpropped by opinion polls and surveys are often predicated on supernatural phenomena because of the centrality of religion to almost everything Nigeria (Ayantayo 2009; Onapajo 2012). These days, some pastors, prophets and other individuals - who have, or are believed to possess, spiritual powers - are becoming increasingly vocal about election matters (Nwolise 2015). They have thus become rallying points for politicians who seek their blessing and the support of their followers (Burgess 2015). According to Nwolise, "The voices of prophets have attracted the attention of millions of people in Nigeria and abroad with questions being raised. Thus, prophets have come to occupy a high-profile position over electoral and existential matters in contemporary Nigeria" (Nwolise 2015, 3).

Religious leaders use prophecy, which is believed to be speaking the unalterable mind or will of God which cannot be deciphered through natural means, to engage with the political establishment (Nwolise 2015). They try to foretell the future (Edewor 2008) and convey extrasensory, divine message about a particular situation, time, and place (Ikem, Ogbonna, and Ogunnubi 2020; Yong 2004). Other spiritual election predictors have become commonplace in Nigeria's bourgeoning democracy and have continued to give their spiritual positions in preand post-election periods. They perform these acts within their rights as enshrined in the Nigerian constitution which guarantees freedom of speech. However, there is a sense in which their utterances, especially when spurred by political bias, may portend serious threats to the country's fledgling democracy.

It is against this backdrop that this article sets out to interrogate the nuances of spiritualized politics in Nigeria with focus on elections in Nigeria, particularly, presidential elections often underlain with spiritual modes of explanation such as prophecy and spiritual prediction. The 
article is divided into sections, starting with an introduction, and followed by an overview of presidential elections in Nigeria. The next sections deal with the politicization of public opinion polls and case studies of electoral prophecies and presidential candidates/parties in Nigeria. This is followed by the section that focuses on implications of electoral prophecies on state institutions such as security agencies and the Independent National Electoral Commission (INEC), while the last section consists of the conclusion and recommendation.

\section{An Overview of Presidential Elections in Nigeria's Fourth Republic}

Elections are an indispensable and sustaining feature of democracy. Periodic elections are expected to be conducted to fill political offices at the expiration of tenures or as circumstances demand. Elections are a medium through which citizens exercise their rights to be involved in government directly or through freely chosen representatives. The overriding philosophy behind elections is that the will of the people should be the basis for governmental authority. While conduct of elections has been emphasized and recognized as fundamental to democracy, there is a need to look at the contexts within which they are conducted (Adejumobi 2000). Studies on elections in Africa have revealed contentious views rooted in conceptual effervescence on one hand, and contextual peculiarity, on the other.

Regardless of the peculiarity of Africa's political terrain, conduct of elections has come to stay in Africa, and specifically in Nigeria. It has been argued that the frequency of elections in Africa, and particularly in Nigeria, despite the inherent flaws, has democratizing effects (Lindberg 2006). Some scholars have, in the same vein, argued that elections must not necessarily be free and fair to be given the common coloration of meeting certain normative standards (Morse 2018). This argument is hinged on the belief that regularity of elections over time will gradually lead to improved outcomes and foster the entrenchment of required democratizing values. As elections become normal in a democracy, there will be emergence and growth of civil society groups (CSOs) and media outlets that will help open up the political space, create a vibrant political culture and strengthen some state institutions (Morse 2018). This, to a large extent, will make the reversal of democratic trends and/or gains impossible (Gyimah-Boadi 2015). Consequently, frequency of elections will guarantee democratic consolidation and institutionalization of transfer of political power (Posner and Young 2008; Lindberg 2006).

It is a fact that however that the democratizing effects of periodic elections may differ from country to country. Hamalai, Egwu, and Omotola (2017) note that election outcomes reflect the political and historical peculiarities of each country. Therefore, generalization cannot be reached based on what is obtainable in one country, whether developed or developing, as a yardstick to judge the performance or credibility of elections in other countries. What is fundamental, however, is that elections could be said to have democratizing effects in any political system where minimum democratic features such as political participation, competitiveness, accountability, and legitimacy are guaranteed (Hamalai, Egwu and Omotola 2017). To this end, frequently conducted and contested elections may generate a level playing field for all parties regardless of incumbency or opposition, as likely outcomes may favor any competing party (Posner and Young 2008).

Nigeria has conducted quite a number of presidential elections since independence from British colonizers in 1960, even though there were disruptions from the military before 1999which marked the end of military incursion in Nigeria. From the first, post-military election that produced President Olusegun Obasanjo in 1999 to the last election conducted in 2019 which returned President Buhari for second term in office, there have been a number of nagging issues bordering on rigging, voter intimidation, and violence, among other things. Presidential election in Nigeria is unarguably the bitterest contest in Nigeria as it is underlain with by-fire-by-force attitude. The reason for this is not farfetched. Politics has become the single, most desirable means of accessing wealth and solidifying one's economic base in Nigeria. One of the 
manifestations of the issues inherent in the manner presidential elections conducted in Nigeria is politicized public opinion polls, and it will be discussed in the next section.

\section{Politicized Public Opinion Polls in Nigeria}

Public opinion polls are avenues for discursive public engagement and inclusivity that give vibrancy to any modern democracy. The importance of polls cannot be over-emphasized particularly in a democracy, as it inextricably link citizens to their elected officials, by providing information expressed by them to policymakers about what they feel concerning issues of the day (Moy and Rinke 2012). However, as regards election polls, scholars have debated the claims of influence it may have on voters' choice and ultimately, the outcome of election result. Most prominent theory in this regard is the bandwagon effect theory. It suggests that voters will be more likely to support a party or candidate if they are on the rise in the polls, and that such party or candidate will eventually attract undecided voters (Aalberg and Aelst 2014; Dahlgaard et al. 2016). In order words, it is also accepting majority view as regards policy matters, election, or any other social issue due to exposure to media reports on polls (Marsh 1985; Moy and Rinke 2012; Arnesen et al. 2017). In contrast, the underdog effect theory claims that a weaker or trailing party or candidate benefits from published polls through attracting sympathy votes (Marsh 1985; Aalberg and Aelst, 2014). Nonetheless, there seem not to be any consensus on the effects of polls as various studies; including both experimental and survey have provided variety of evidences of bandwagon effects in elections (Schmitt-Beck 1996; Moy and Rinke 2012; Stolwijk, Schuck, and Vreese, 2017). For instance, Stolwijk, Schuck, and Vreese (2017) argue that emotions such as anxiety and enthusiasm mediate the effect of poll exposure on vote choice. In other words, polls has the capacity to alter intended voter's decision to vote for a particular candidate or party, reinforce the predisposition to vote for the winning party, and compel undecided voters to join the crowd. They further discovered that voter's increased likelihood to vote for a party after exposure to more positive poll coverage about that party (Stolwijk, Schuck, and Vreese 2017), giving rise to the fear of preelection polls even in advanced democracies in the West. Even political elites in some of these countries have equally advocated for a ban on pre-election polls, especially on exit-polls (Aalberg and Aelst, 2014; Dahlgaard et al. 2016). According to the 2017 joint report of the World Association for Public Opinion Research and ESOMAR (the Global Voice of the Data, Research and Insights Community), out of 133 countries that were surveyed, 79 of them were reported to have imposed some sort of embargo or blackout period which restrained the publication or release of pre-election polls. In certain circumstances, the blackout makes voters to be vulnerable to "misinformation from other sources - information that cannot be verified" (Frankovic, Johnson, and Stavrakantonaki 2018, 7).

Likewise, Lewis-Beck (2005) rightly notes that election forecasting has a political side. And as a result, polls may be compromised in favor of a political party or candidate, by presenting to the public faulty outcome of polls. This is what seem to be plaguing emerging democracies in Africa. Ansu-Kyeremeh (1999) study of local polls organized by newspaper during the 1996 presidential and parliamentary elections, which was its transitional period from authoritarian rule, found that polls were unprofessionally conducted mostly permeated with unscientific procedures and inaccuracies. While this observation may be understood given the fact that the country was just emerging from a dictatorial era, where the freedom of speech was suppressed and the lack of adequate poll reporting knowledge among journalists contributed to undermine the exercise. On the contrary, that arguably may not be the case with Nigeria, having experienced several elections in the present democratic dispensation and the freedom of speech is largely respected.

More importantly, political parties in Nigeria seem to appreciate the bandwagon effects of public opinion polls in attracting attention and substantial undecided votes to them. This is because, during election campaigns, polls remain a huge chuck of news media coverage, 
particularly with focus on predicted scores of candidates and parties (Aalberg and Aelst,2014). The reality of public opinion polls and election prediction in Nigeria is captured by Adibe thus:

Do election predictions really matter? Yes, they do. For parties that are predicted to win, (especially by the major international institutions such as The Economist, Brookings Institution and the leading political/financial risks analysts), such predictions could provide a boost and create a bandwagon effect by unwittingly nudging voters to a particular political preference. In essence, election predictions could create a selffulfilling prophecy - which is why some candidates in Nigerian elections procure favorable prophecies from 'Men of God' or organize fake opinion polls. (2018)

It is no longer news that surveys and opinion polls in Nigeria are muddied in contradictions inherent in intense power struggle by politicians who are unconcerned about democratization and standardization of the electoral process.

In 2014, an online news platform, Sahara Reporters, conducted a pre-election opinion poll to examine the preference of Nigerians with respect to their preferred candidate for the 2015 presidential election. At the end of the exercise which lasted for twenty-four hours only, 15,435 persons polled their opinions. Out of the total number that voted, 12,246 individualsrepresenting 79 percent of voters - chose the then All Progressives Congress (APC) candidate, Muhammadu Buhari, as their preferred candidate. The incumbent President, Goodluck Jonathan of the People's Democratic Party (PDP), who was seeking re-election, got 3,189 votes (Tukur 2014). Irked by this outcome, Reno Omokri, the Special Assistant to President Jonathan, set up a similar poll on social media to ascertain whom Nigerians would vote in the 2015 presidential election. The goal essentially was to counter the previously unfavorable poll and to put to test their belief that the poll was skewed in favor of APC candidate. Regrettably, the Omokricommissioned opinion poll still gave unfavorable result to his principal. The poll lasted for four days and the total number of votes was 9,176 . Out the total votes, 6,411 votes, representing 69.87 percent of the total votes, were in favor of the APC candidate, while the PDP candidate got 2,455 votes, representing 26.75 percent of the total votes. 310 votes, representing 3.38 percent of the total votes, were undecided (Tukur 2014). President Jonathan's party (PDP) was concerned by this development, hence, the party mobilized its members and affiliate campaign outfits such as the Transformation Ambassadors of Nigeria (TAN), and the Goodluck Support Groups (GSGs) for another opinion (Tukur 2014). This time, President Jonathan garnered 13,111 votes to overtake his leading opponent, APC's Muhammadu Buhari, who got 12,875 votes. It is noteworthy that immediately this poll gave a marginal lead to the President, it was shut down. That would not be the first-time polls organized by PDP apologists would be abruptly concluded. It is on record that polls conducted by Africa Independent Television (AIT), which gave the APC candidate continuous lead over his People's Democratic Party (PDP) opponent was brusquely discontinued because the founder of the television station is affiliated to the PDP. These few cases are indicative of lack of objectivity which will eventually render the outcome of electoral surveys in Nigeria unreliable.

During the electioneering process for 2019 presidential election, some foreign, professional polling firms were employed by the two major political parties in Nigeria-APC and PDP. These firms reeled out varying predictions of the election outcome. Some professional polling firms reportedly predicted President Muhammadu Buhari's victory. These included Control Risks (London-based firm), Eurasia Group (New York-based firm), NKC African Economies (South Africa-based), and Capital Economics (London-based research firm) (Wallace 2019). Their prediction was hinged on some factors which included a) the apparent aloofness of PDP Governors from the South-East geopolitical zone to the candidacy of PDP's flagbearer; b) cult followership enjoyed by APC's candidate in Northern Nigeria; and c) the possibilities inherent in power of incumbency held by the candidate of the APC who doubled as the sitting president. 
Conversely, PDP's Atiku Abubakar was also forecast as the winner of the election by London-based The Economist, Fitch Solutions (London-based research outfit), Songhi Advisory (Lagos-based firm), Teneo Intelligence (based in New York), and Verisk Maplecroft (Londonbased firm) (Wallace 2019). They premised their prediction on such variables as failure of Buhari-led government to fulfill its previous electoral promises; the backing of very important powerbrokers across ethno-regional boundaries, such as ex-presidents and former military leaders/generals; and, the increasing spate of insecurity across the country. Perhaps the most assuring of the predictions for the PDP was by a US-based polling firm, Williams and Associates. It was this firm that predicted that President Jonathan would lose to General Muhammadu Buhari in 2015 even though it had been hired by President Jonathan. So, when this firm predicted that APC's Buhari and Nigerian President would lose to PDP's Atiku Abubakar in 2019, it was considered a fait accompli. Surprisingly, the reverse turned out to be the case as Buhari won the election, although without the PDP and Atiku Abubakar conceding the defeat as the reflection of what transpired at the presidential election.

From the foregoing, it remains to be seen how surveys, opinion polls and electoral predictions affect outcomes of elections in Nigeria despite claims by professional pollsters about objectivity and rigorous scientific process involved in those surveys and predictions. A key issue here is that these polls are often without unanimity, perhaps because they are compromised by politicians or because of preconceived bias of the pollsters. On the other hand, the unreliability of electoral surveys and predictions in Nigeria may be as a result of the fact that they inform political parties' recoiling of their strategies and improve in areas where they are lagging behind. However, Nigerian politicians have often turned to supernatural means regardless of what the polls are saying. The next section will discuss this in detail.

\section{Spiritualizing Nigeria's Electoral Process}

As mentioned earlier, the spiritual dimension to politics and elections is a largely ignored aspect of political studies in Nigeria, and Africa. Ayantayo (2009) explains the phenomenon of spiritualization of electoral process thus: "Spiritualization of electoral process connotes the act of taking spiritual or supernatural realm into politics thereby creating an impression that success in election is independent of wisdom, foresightedness, logical plan, widespread political tour and good campaign, adequate political logistics, and people-oriented political manifestoes but by divine intervention or divine help, manipulation and inducement" (Ayantayo 2009, 101)

One of the copious ways spiritualizing politics manifests in Nigeria is through the use of God and religious tone by politicians when engaging with the electorate. Rather than use terms which speak to their understanding of the issues that affect the electorate and what they intend to do about them, in terms of policy manifestoes, they would rather appeal to the religiosity of the people using the name of God and asking them to be trusted with power. Consequently, political campaigns are suffused with religious symbolism to denote that their involvement in politics is divinely sanctioned. This was the case of the National Party of Nigeria (NPN) in the Second Republic, which electoral promises were underpinned by religious symbolism and narratives deemed to be nobler than mundane promises of other political parties. Unfortunately, the depiction of its logo with one finger soon aroused suspicions and insinuations from Christians that the NPN had islamization agenda (Ayantayo 2009). On the other hand, the use of two fingers by the Unity Party of Nigeria (UPN) was construed by the Northerners who are mainly Muslims to be a representation of polytheism, which is forbidden in Islam. Subsequently, whether explicitly or implicitly, other political parties both in the Second Republic even to the present dispensation, have largely characterized most of their political activities/campaign with huge amount of religious features/appeal.

Ayantayo (2009) argues that the excessive invocation of religious symbolism is a diversionary tactic which may not work all the time. Some political scientists have attributed it 
to lack of ideological inclination by Nigerian political parties (Omotola 2009; Saliu and Ifejika, 2017). While we may agree that spiritualizing the electoral process is a diversionary tactic mainly employed by political actors, it may not be tenable, in the face of empirical facts, to attribute it to lack of ideological based by political parties. Already, Ibeanu (n.d.) has argued vociferously against this view and maintained that political parties in Nigeria are ideological formations. Chapter II of the 1999 constitution (as amended), according to him, espouses the pursuit of liberal-welfarist ideology by political parties, even though, arguably, they face crisis of ideology. More importantly, section 224 of the said constitution stipulates that programs, aims and objectives of political parties should conform to the ideological provision in Chapter II of the constitution. However, the crisis of ideology arises from the fact that rather than acquiescing to the national ideological framework enunciated in the constitution, liberal welfarist ideology, political actors mainly subscribe to self-enrichment ideology. Therefore, this inherent contradiction seems to create the erroneous unanimity among scholars about the absence of ideological base of politics in Nigeria. Manifestly, politicians in Nigeria are unashamedly, addictively attracted to bourgeois ideology since it gives primacy to the capture of power, excessive individualism and opportunism.

The drive to capture power for personal gains accounts for the crooked path Nigerian politicians are willing to take. One of the agencies through which politicians think that they can do this is religionizing and spiritualizing politics. Ayantayo succinctly explains it thus:

The impression the public and politicians do have is that electoral issues are better settled spiritually through (sic) prayers, manipulation of angelic beings and the use of magic than making appeals to political wizardry. Some candidates practically demonstrated this by boasting that if certain groups of people refused to vote for them, then, some natural objects like stones, pebbles and leaves would instead vote for them. Counting on this, some politicians did express their much reliance on the power of prayer or magic to win election...With the use of charm, magic and occultic powers to either threaten political opponents to withdraw in election contest or at times to threaten the electorate not to vote for candidates of their choice even after they might have been convinced of the need to do so going by the content of political manifestoes such parties or individuals might have presented to the populace during campaigns. $(2009,101)$

Driven by the ideological disposition to capture power at all costs, Nigerian politicians will go to any length even if it means engaging in occultic practices. Without doubt, this largely explains why many Nigerians view politics as a dirty venture. To drive the point home, a few instances that buttress the do-or-die attitude of politicians in Nigeria will be looked at here. In 2018, a video showing a former Majority Leader of the Osun State House of Assembly, Timothy Owoeye, naked in the dead of the night went viral. According to the opposition political party in the State, PDP, the lawmaker was bathing with blood in a market square in order to spiritually facilitate the All Progressives Congress win in the Osun State governorship election, as well as for him to remain politically relevant (Makinde 2018). Also, the Okija Shrine saga in 2004 revealed how political candidates were made to visit the shrine to swear oath of allegiance to the godfathers in the event that they are elected. Prior to his election as Governor, the former Governor of Anambra State Dr. Chris Ngige was taken to the shrine by his political godfather, Chris Uba, in order for him to keep his side of the bargain after winning the governorship election (Ujumadu 2015). Apparently, this event lays bare the possible transfer of accountability to a person (godfather) mediated by a local deity in contrast to the claim of elected officials that they represent the people's mandate. In expounding the pervasiveness of supernaturalism in Nigeria's electoral process, a former Presidential aide, Reuben Abati (2018) rightly notes that: "in the majority however, you will find those who will claim that they are responding to a Divine call. They have been told by a Pastor (especially a General Overseer of one of these miracle-dispensing churches) 
or an Imam (sorry a Sheik in Mali, Senegal, Niger, Guinea Bissau, and in-country, a Sheik in llorin, Osogbo, Bauchi, Maiduguri). They all rely on these pastors and imams or the covenants that they enter into in fraternities and cults" (Abati 2018).

The preponderance of supernatural modes to politics in Nigeria is so acute that most politicians actually believe that power is from God and He gives it to whomever He pleases. These supernatural and spiritual dimensions are more important to them than popular support and their electoral appeal. Therefore, regardless of any human agency, God's predetermined will must be done regardless of whether people support a candidate or not (Ayantayo 2009). This perhaps explains why internal democracy is lacking within political parties in Nigeria. Some candidates are seen as "anointed candidates" or the "chosen ones," hence the circumvention of party rules and procedures to impose them on the parties.

It is noteworthy that supernaturalism is ingrained in African worldview and despite years of modernity, people still find themselves resorting to spiritual phenomena, especially when science cannot provide them with the kind of answers they would prefer. Precolonial African leaders (kings) combined political and spiritual authority. They also would often consult with shamans, herbalists and cult priests for spiritual guidance on issues that affected their domains. Evidently, the vestiges of that intricate relationship between politics and supernaturalism still remain with us till today. It is no surprise therefore that during election periods in Nigeria, political office-seekers frequent churches, mosques and other spiritual locations to receive fortification, direction and endorsements. This is not to say that in developed societies politicians do not visit religious leaders for endorsements. However, they do not hinge their victory on supernatural powers or influence as their counterparts in Nigeria. It has become a norm in Nigerian politics, and it is fast becoming a means by which spiritualists and religious leaders seek relevance and try to have their own bite of national cake. For instance, Satguru Maharaji advised President Muhammadu Buhari to come and see him for spiritual guidance in order to win the 2019 presidential election. As a matter of fact, he had mentioned that the failure of President Jonathan to visit him when he asked for the President's audience before 2015 was responsible for his defeat at the poll (The Nation 2018).It is on record that Col. Sambo Dasuki (Rtd), the former National Security Adviser to Goodluck Jonathan, allegedly used part of the funds allocated to his office for the procurement of arms to fight insurgency in the North-East to pay marabouts from Saudi Arabia and other African countries. He secured the services of these people to seek their intervention toward his principal's re-election (ICIR 2015). The phenomenon of spiritualizing electoral politics implies recognizing either wrongly or rightly the fact that winning election is not only independent of political sagacity but requires some supernatural assistance (Ayantayo 2009). These politicians believe that electoral success is an outcome of predetermined influence of supernatural forces capable of helping them to sway the electorate in the direction of a candidate.

Increasingly, the manifestation of this spiritualized form of electoral politics is through the expression of divine predictions claimed to be revealed through supernatural and/or spiritual agencies. To this end, prophetic declarations about who wins or loses have become part of electoral politics and electioneering process in Nigeria (Burgess 2015). This situation is similar to what happens in Nigeria's sister country, Ghana, where neo-prophetic pastors, with claims of being anointed to be gatekeepers of the country, profess their ability to renegotiate with God to change his purpose on both individuals and entities (Acheampong 2018). On this wise, any political office-seeker maybe considered by the electorate only if they are divinely revealed, through their prophetic mandate or declarations. The next section will bring to the fore electoral prophecies affecting presidential candidates and parties in Nigeria. 


\section{Electoral Prophecies on Presidential Candidates and Parties in Nigeria}

The incursion of prophecies and supernatural predictions into Nigeria's political landscape can be traced to military junta characterized with excessive political oppression of dissents who sought reforms from the military occupation. Amidst this toxic environment, the socioeconomic conditions of the people worsened. Thus, there was a gradual movement away from the State to other significant self-governing economic, sociocultural, and juridical systems (Osaghae 1999). Lamentably, the 1980s and 1990s marked unprecedented number and forms of retreat from the State (Osaghae 1999), which then led to the proliferation of groups, particularly, religious groups. By this time, prophecies against military rule-commonly equated as the rule of wickedness-were released from different religious leaders particularly, Pentecostal pastors. The most prominent of them was the one given by Pastor Tunde Bakare. In 1993, Pastor Tunde Bakare gave a shocking prophecy about the futility of the transition program of General Ibrahim Babangida to hand over to a democratically elected government. He proclaimed that "SDP will fail, be cut off and swallowed up. The military will fall" (Whistler 2017). Earlier, he had through his prophecy tried to dissuade the candidate of the Socialist Democratic Party, MKO Abiola, from contesting the 1993 presidential election, because the transition program of the General Ibrahim Babaginda-led junta was a hoax to distract the nation from the deteriorating socioeconomic condition of people caused by the military. These prophecies generally dampened the high hopes of Nigerians in their anticipation for regime change through a democratic process. As it turned out, his prophecies were fulfilled. Pastor Tunde Bakare soon became a respected prophet and leading political watchdog in Nigeria (Edewor 2008).

When General Ibrahim Babangida was Nigeria's military Head of State, Pastor Tunde Bakare prophesied about eventual exit, and the evanescent nature of the transitional government General Babangida would foist on the nation after annulling what would be the generallyacclaimed free and fair presidential election of 1993. Seeing that his regime was far losing legitimacy both within and outside Nigeria as a result of its ignoble role it played in truncating democratic transition in Nigeria, General Babangida quickly constituted a transitional government headed by Ernest Shonekan, which would handle the affairs of the nation until a democratic process would be initiated to bring in a new government. Unfortunately, the transitional government had only lasted for three months when it was booted out of office in a bloodless military coup led by General Sani Abacha. To many Nigerians, General Abacha regime was seen as a dark era in Nigeria's history. The regime suppressed any form of opposition and dealt ruthlessly with dissents. Civil activists were detained and killed while the lucky ones among them exiled in other countries. It was during this period that Nigeria became a Pariah State as the country was suspended from some international organizations and isolated by the international community.

Among the regime critics who were quite vocal was Pastor Tunde Bakare. As General Abacha planned transition program from military to democratic rule in which he also would contest as presidential candidate, Pastor Tunde Bakare was widely reported to have shared a vision God showed him about the intrigues and wasteful outcome of the election. He states thus: "In an open vision, I saw over thirty political heavyweights jostling for the presidency of the country. Even with their money, manipulators set in to tamper with election results, which brought in confusion into the whole process. Three ugly things will characterize the transition program - betrayals, deception, and intrigues - and the gullible and the desperate will have their political career terribly shattered" (Whistler 2017).

As a matter of fact, General Abacha coerced other political parties who had prepared to partake in the presidential election to adopt him as their presidential candidate. Amazingly, the five prominent political parties obliged, which apparently paved the way for the General to 
succeed himself. About that time, there was an alleged coup attempt to overthrow General Sani Abacha's regime which allegedly involved top military brass including Abacha's Deputy, General Oladipo Diya. The culprits were subsequently sentenced to death. Before the sentence could be carried out, Pastor Tunde Bakare, declared that "Just before the killer will kill, he himself will be killed. Expect the night before miracle" (Whistler 2017). This prophecy foretold the death of the maximum ruler. Inexplicably, General Sani Abacha's sudden death occurred in June 1998 before he could carry out the sentence of the alleged coup plotters. His death sent wild celebrations across the country. It was at this point that political prophecy became a phenomenon in Nigeria's polity. The influence of prophecy continues to grow since return to democratic rule in 1999.

Another prophet who gave political prophecies, during the military regime and succeeding civilian democratic government, is Prophet Anthony Nwoko. For instance, he once said: "I had told IBB in 1993 to leave office and it happened. I prophesied that Abacha would leave office mysteriously, and you saw what happened" (Nwodo 2016.). The following statement was also credited to him, "Don't take my prophesies for granted. I had told General Abdulsalam Abubakar not to make Obasanjo President and I had also warned General Obasanjo not to make late former President Yar'Adua president but my advice was not heeded. You saw what happened" (Nwodo 2016).

While these prophecies are increasingly becoming prevalent in the public space and discourse of various national issues, election periods have remained the peak for reeling out prophecies. Nwolise (2015) notes that prophets have come to occupy a high-profile position over electoral and existential matters in contemporary Nigeria. Particularly, 2015 presidential election saw an upsurge in political prophecies in a way that is not healthy for any growing democracy. There were many prophecies that predicted that the then President, Goodluck Jonathan, would be returned elected. Interestingly, the election result turned out to the contrary. According to the result released by the Independent National Electoral Commission (INEC), the candidate of All Progressives Congress (APC), Muhammadu Buhari scored 15,424,921 votes to trounce his main opponent, Goodluck Jonathan, who got 12,853,162. President Jonathan, to everyone's surprise, graciously conceded defeat. Table 1 below documents the prophetic pronouncements of acclaimed religious leaders concerning presidential elections in Nigeria. 
Table 1: Showing Various Prophetic Declarations Concerning

Presidential Elections by Acclaimed Religious Leaders

\begin{tabular}{|c|c|c|c|}
\hline $\mathbf{S} / \mathbf{n}$ & Name & Political Prophecies & Sources \\
\hline 1 & $\begin{array}{l}\text { Primate } \\
\text { Theophilus } \\
\text { Olabayo }\end{array}$ & $\begin{array}{l}\text { Power will remain in the North in } 2023 \text {. } \\
\text { We should not be fooling ourselves. All the } \\
\text { money that politicians in the South West } \\
\text { are spending in anticipation of winning the } \\
2023 \text { presidency will not go anywhere...A } \\
\text { new party will emerge; APC and PDP will } \\
\text { fizzle out before } 2023 \text { because a new dawn } \\
\text { is coming }\end{array}$ & (Nwachukwu 2020) \\
\hline 2 & $\begin{array}{l}\text { Prophet } \\
\text { Wale } \\
\text { Olagunju }\end{array}$ & $\begin{array}{l}\text { God said it would take his own } \\
\text { intervention for the present government to } \\
\text { survive total defeat by the Peoples } \\
\text { Democratic Party. God said Buhari had } \\
\text { become a disappointment in his sight and } \\
\text { he (God) had sought and found a man after } \\
\text { his heart to replace him. As a result, God } \\
\text { said the road to Aso Rock Villa for Atiku } \\
\text { was now very clear as his name would } \\
\text { continue to ring a bell and that many would } \\
\text { still root for him. }\end{array}$ & (Alagbe 2020) \\
\hline 3 & $\begin{array}{l}\text { Prophet } \\
\text { Temitope } \\
\text { Aduroja }\end{array}$ & $\begin{array}{l}\text { The incumbent President (Buhari) will } \\
\text { have no choice but to accept defeat. Once } \\
\text { the new President emerges, the present } \\
\text { Governor of Osun State (GboyegaOyetola) } \\
\text { should get ready to vacate office because } \\
\text { the man who truly won the election will } \\
\text { reclaim his mandate }\end{array}$ & (Alagbe 2020) \\
\hline 4 & $\begin{array}{l}\text { SatguruMah } \\
\text { araji }\end{array}$ & $\begin{array}{l}\text { Elections are for human beings. This is the } \\
\text { time to call a spade a spade. Buhari is } \\
\text { there. He has another term in the office. I } \\
\text { don't see Atiku, Ezekwesili, Sowore and } \\
\text { others as president. I believe, if they will } \\
\text { listen to me, they should not think of going } \\
\text { to elections. }\end{array}$ & (Olafioye 2019) \\
\hline 5 & $\begin{array}{l}\text { Prophet } \\
\text { Ekong Ituen }\end{array}$ & $\begin{array}{l}\text { Let me start by telling Nigerians that } \\
\text { election result will spring surprises, but in } \\
\text { my revelation, it has been established that } \\
\text { President Muhammadu Buhari of All } \\
\text { Progressives Congress (APC) will win the } \\
2019 \text { presidential election. You may not } \\
\text { like him, but that is the truth }\end{array}$ & (Olafioye 2019) \\
\hline 6 & $\begin{array}{l}\text { Bishop Wale } \\
\text { Olagunju }\end{array}$ & $\begin{array}{l}\text { Let me congratulate President } \\
\text { Muhammadu Buhari for winning the ticket } \\
\text { of his party, the All Progressives Congress, } \\
\text { and let me also make it clear to him that he } \\
\text { will lose to Atiku Abubakar. Let me also } \\
\text { congratulate Atiku in advance because he } \\
\text { will win the next presidential election come } \\
2019 \text {. }\end{array}$ & $\begin{array}{l}\text { (Adeniyi and Omogbolagun } \\
\text { 2019) }\end{array}$ \\
\hline
\end{tabular}




\begin{tabular}{|c|c|c|c|}
\hline $\mathbf{S} / \mathbf{n}$ & Name & Political Prophecies & Sources \\
\hline 7 & $\begin{array}{l}\text { Prophet } \\
\text { Emmanuel } \\
\text { Stephen }\end{array}$ & $\begin{array}{l}\text { Between Atiku and Buhari, I said } \\
\text { something in my earlier prophecy. As } \\
\text { Atiku walked to sit on a throne decorated } \\
\text { with the country's colors, someone came } \\
\text { and removed the throne and he sat on the } \\
\text { floor. Last December, I said when the } \\
\text { throne reappeared; the current President } \\
\text { Buhari already sat on it. }\end{array}$ & $\begin{array}{c}\text { (Adeniyi and Omogbolagun } \\
\text { 2019) }\end{array}$ \\
\hline 8 & $\begin{array}{l}\text { Prophet } \\
\text { David } \\
\text { Babalola }\end{array}$ & $\begin{array}{l}\text { I can go back for the good to come. For } \\
\text { you to have the best, that means there is } \\
\text { bad before the good. It is power } \\
\text { turnaround. I look at the announcement } \\
\text { they announced (sic). They said Atiku have } \\
\text { (has) won the presidency. Let everyone } \\
\text { pray effectively that they will hand over. }\end{array}$ & $\begin{array}{c}\text { (Adeniyi and Omogbolagun } \\
\text { 2019) }\end{array}$ \\
\hline 9 & $\begin{array}{l}\text { Primate E.O. } \\
\text { Akeju }\end{array}$ & $\begin{array}{l}\text { God said President Muhammadu Buhari } \\
\text { will be disgraced just like his predecessor } \\
\text { if he re-contests }\end{array}$ & (The Nation 2019) \\
\hline 10 & $\begin{array}{l}\text { Prophet } \\
\text { Okechukwu }\end{array}$ & $\begin{array}{l}\text { God told me that any man that would want } \\
\text { to stop Atiku from entering will go down } \\
\text { and might not witness Atiku's celebration } \\
\text { of victory...I saw a different thing } \\
\text { altogether. It was not free and fair. But } \\
\text { children of God have prayed against } \\
\text { that...My message to Nigerians is to go out } \\
\text { and obey the mind of God. He has chosen } \\
\text { Atiku...Even if we are } 100 \text { in Nigeria and } \\
10 \text { decide to cast their votes, a greater } \\
\text { percentage will vote for Atiku. Whether we } \\
\text { vote or not, Atiku will definitely win. }\end{array}$ & (The Nation 2019) \\
\hline 11 & $\begin{array}{l}\text { Rev. Fr. } \\
\text { EjikeMbaka }\end{array}$ & $\begin{array}{l}\text { As I was waiting on the Lord, I'm asked to } \\
\text { advise you, don't come out for second } \\
\text { tenure; after this, retire peacefully...Those } \\
\text { who are encouraging you to come out and } \\
\text { run again want to disgrace you shamefully } \\
\text { and publicly }\end{array}$ & (Onyeji 2018) \\
\hline 12 & $\begin{array}{l}\text { Pastor Chris } \\
\text { Omatsola }\end{array}$ & $\begin{array}{l}\text { President Muhammadu Buhari is God's } \\
\text { mandate for } 2019 \text {. God said he is giving } \\
\text { President Buhari another opportunity to } \\
\text { make History. Here is his opportunity to } \\
\text { leave a legacy as he has always desired in } \\
\text { his heart that Nigerian will never forget } \\
\text { him...I see surprise victory for APC. APC } \\
\text { winning more states and spreading more in } \\
2019 \text {. Adams Oshiomole leadership in APC } \\
\text { will benefit the party spiritually and } \\
\text { otherwise. }\end{array}$ & (Olowolagba 2019) \\
\hline
\end{tabular}

Source: Ikem et al.

From the table above, it is evident that religious leaders have assigned themselves the role of steering the country's political trajectory and geopolitics. The 2019 presidential election had barely been concluded when a priest known for his political predictions, Primate Theophilus Olabayo, claimed that, from divine insight, the North will produce the next president in 2023. According to him, before 2023 General Elections, a new political party will emerge that may 
likely subsume both the ruling party All Progressives Congress (APC) and the main opposition party People's Democratic Party (PDP). First, this prophecy is inherently misaligned considering that the elected President had not even spent a year out of his second tenure before the prophet publicly released the prophecy. Two, the prophecy offends Nigeria's political elite's arrangement that allows for the rotation of power at the center between the North and South. This prophecy as well as others were said to have reinforced the already incendiary atmosphere in the polity especially as anti-North sentiment is rife in the South (Ikem, Ogbonna, and Ogunnubi 2020). The current President, Muhammadu Buhari, is from the North and he is on his second term of four years.

Table 2: Showing The Geo-Political Zones in Nigeria that have Produced President in this Fourth Republic

\begin{tabular}{|l|l|l|l|}
\hline S/n & Date & President & Geo-political zone \\
\hline 1. & $1999-2007$ & Former President Olusegun Obasanjo & South-West \\
\hline 2. & $2007-2010$ & Late President Musa Yar'Adua & North-West \\
\hline 3. & $2010-2015$ & Former President Goodluck Jonathan & South-South \\
\hline 4. & $2015-$ Present & President Muhammadu Buhari & North-West \\
\hline \multicolumn{3}{|c}{ Source: Ikem et al. } \\
\hline
\end{tabular}

The principle of rotation of power was first proposed in the 1995 draft constitution which anticipated the rotation of the presidency among Nigeria's six geo-political zones-North-West, North-East, North-Central, South-South, South-East, and South-West. Although it was not included in the 1999 constitution (as amended), the PDP-led government, which took over from the military in 1999, introduced power rotation as a convention so as to allay the fear of marginalization of ethnic minorities. Other political parties have also tacitly adopted it. It must however be mentioned that the application of the principle has not been inviolable because of the tendencies of the political class to renege on agreements. That said, based on rotational presidency, the South, comprising South-East, South-South and South-West, is to produce the President in 2023. Therefore, anything that upsets this arrangement will be considered as an affront to the South and might destabilize the polity. This is not to say that the South is cohesive. There are intense contestations going on in the South especially between the South-East and South-West as to which of the geopolitical zones will produce the President in 2023. Even though South-South produced the last President from the South before power returned to the North, the region cannot be completely ruled out from the contest that will produce the country's next President. Of the major ethnic groups in Nigeria, only Igbo - of South-East Nigeria - has not had access to the power at the center. Naturally, 2023 election should present an opportunity for the Igbos to produce Nigeria's next President. However, the clamor for Igbo presidency is being threatened by a number of factors. Yoruba (South-West) political elite are very interested in the presidency especially because they played very significant roles in the emergence of the current President and they are the most visible political actors from the South in the ruling party. Regardless of the internal wrangling in the South about 2023 presidential election, there is seemingly a point of convergence by southerners that power must return to the South.

From the foregoing, it is clear that prophecies being reeled out about the North retaining power in 2023 are not in the interest of the country that is already markedly divided. These prophetic proclamations that do not take cognizance of Nigeria's pluralism and political conventions are capable of encouraging political anxiety and deepening the disunity that already exists between the North and South. These prophecies could also gravely impinge state institutions primarily mandated to ensure free and fair elections in Nigeria. Thus, the next section will do a threat analysis on the possible implications of electoral and political prophecies on state institutions charged with conduct and management of elections in Nigeria. 


\section{Impacts of Electoral Prophecies on State Institutions}

Given the pervasiveness of prophetism in Nigerian electoral process, it is important to analyze its implications vis-à-vis its impacts on state institutions statutorily assigned the role of election management in Nigeria. In order to achieve this, we will situate this discourse within the framework of threat analysis. This framework simply affords us the opportunity to highlight possible consequences of electoral prophecies on the integrity or neutrality of state institutions during election periods. Hence, we opted to look at security agencies and the Independent National Electoral Commission (INEC) and the judiciary. One of the critical issues that scholars and commentators have concerned themselves with about Nigerian electoral process is the need for the electoral umpire (INEC) and other state institutions like security agencies and the judiciary to carry out their responsibilities in a way that guarantees fairness and justice. We will start with analyzing how the duties of security agents during elections may be gravely affected by electoral prophecies and supernatural predictions.

\section{Security Agencies}

The safety and fairness of the electoral process can only be guaranteed when there is adequate security to ensure that both materials used for the election, and all categories of people involved in the process are properly secured. The neutrality of security agencies in Nigeria's electoral process has always been a major concern for all stakeholders including local and international development partners. Although as enshrined in the constitution and Electoral Act, the Nigerian Police is the sole security outfit to provide security during elections, insecurity issues in the country have necessitated the need to involve other security arms. Thus, the various security agencies expected to play specific role during elections are guided by the Interagency Consultative Committee on Election Security framework (ICCES). Attoh (2016) notes that this framework has been able to curb electoral insecurity and violence to a considerable extent. Notwithstanding, there have been contentions about the roles played by security agents during elections. Onapajo (2015) notes that, more often than, the use of Police, Army and the Department of Security Services during elections has always been to the advantage of the party in power at the centre. This is not unconnected to the character of the Nigerian State and the reality of centralization of power at the center (Adibe 2015). For instance, Chinwo (2016) illustrates the indiscriminate use of federal might in coercing the chances of electoral victory of the ruling party in Rivers State, Nigeria. In 2017, INEC report found security agencies culpable in electoral fraud (Ndujihe 2017). There appears to be a general perception that security agencies are susceptible to the control of the President. For instance, the last-minute redeployment of Police Commissioners across the country was seen as a politically calculated attempt to favor the ruling All Progressive Congress (APC) in the recently concluded 2019 general election. In fact, the People's Democratic Party (PDP) accused the Inspector General of Police of carrying out the orders of the presidency (Akinkuotu and Adepegba 2019). Although the Police denied it, however, the perception of police partisanship is rife in Nigeria. Cases such as Ekiti and Osun States' elections in 2018 and 2019 General Election have seen INEC accuse the Nigerian Army of disrupting election because of political interests (Adedigba and Adebayo 2019).

Given this kind of atmosphere, electoral prophecies in favor of a particular political party may be used as justification by security agents to commit electoral malfeasance in favor of the candidate or party the prophecies favor. Electoral prophecies may also lead the electorate to conclude that the security agencies have shown bias if the candidate or party predicted by these prophets and spiritualists fails to win. This situation may threaten the legitimacy that security apparatus of the country should have. 


\section{Independent National Electoral Commission (INEC)}

The conduct and management of Nigeria's electoral process is solely the responsibility of the Independent National Electoral Commission. The Commission is constitutionally mandated to conduct elections for all national elective positions, governorship and State Houses of Assembly. The Commission is required by law to discharge its responsibilities with fairness, transparency and integrity. Consequently, the Commission has introduced some reforms to ensure and enhance that elections reflect the will of the people. Regardless, INEC still does not enjoy sterling reputation because of its past and recent electoral crimes committed by some of its ad hoc and permanent staff. Omenma (2019) argued that INEC has continued to suffer from credibility gap because INEC, as an agent of the presidency, continues its tradition of manipulating and rigging the elections in favor of the ruling party. A major contention against INEC is that even though its name suggests its independence, it is hardly independent (Omotola 2010). This is because the appointment of the national chairman and other federal commissioners is made by the President. It also is not financially autonomous, hence, may not be free from political interference.

In spite of these issues, the Commission has been trying to reinvent itself through restructuring and adjusting some of its activities to demonstrate its resolve to adhere to and uphold the principles of fairness and transparency to all. The immediate former Chairman, Prof. Attahiru Jega, brought sweeping reforms and committed to free, fair and credible elections. His successor, the current Chairman, Prof. Mahmood Yakubu, has also demonstrably committed to putting the Commission on sound footing by ensuring that elections are reasonably free and fair. Since 2011, Collation and Returning Officers are no longer INEC staff but academics selected across Nigerian universities. Supervisory Presiding Officers, Presiding Officers and Assistant Presiding Officers are picked from the National Youth Service Corps (NYSC) members. The Commission also introduced the use of card reader machines to the voting process and systematized the involvement of civil society organizations and election observers - both local and foreign - in the election process. INEC has been at the vanguard of the call for the establishment of an agency of government that will be charged with prosecuting electoral frauds and malfeasance.

With all these reforms, INEC still has a long way to go with respect to gaining public confidence and delivering acceptable elections. Therefore, prophetic declarations for or against a party or candidate may further erode the petite confidence that people have in INEC. In the same, given the volatile atmosphere elections are conducted in Nigeria, prophetic declarations may incentivize people to reject election outcomes even when the winners have emerged through credible elections. In some cases, these prophecies are capable of fueling post-election violence. A case in point is that of Niger Delta militants who had vowed to unleash mayhem on the country if President Jonathan was not declared the winner of 2015 presidential election (Ikem, Ogbonna and Ogunnubi 2020). Jonathan lost to APC's Muhammadu Buhari despite the plethora of prophecies saying he would be re-elected. Perhaps the only reason why the country was not up in flames after the election was how swiftly President Jonathan conceded defeat, called General Buhari to congratulate him and pacified his supporters to maintain peace. Also, in the fiercely contested 2019 presidential election, former Vice-President, Atiku Abubakar who ran on the platform of the PDP lost to the incumbent President, Muhammadu Buhari of the APC. Partly, due to prophetic declarations in favor of Abubakar, he refused to accept the result declared by INEC. Rather, he opted for a result allegedly transmitted to unknown INEC server which showed him scoring 18,356,732 votes to defeat Buhari who allegedly got $16,741,430$ votes (Yahaya 2019). 


\section{Judiciary}

Judiciary is a cardinal institution in any established democracy (Ojo 2011). It is the arm of government that serves as the arbiter in election disputes in Nigeria. However, there are issues about the neutrality and impartiality of the judiciary in dispensing justice with respect to postelection disputes in Nigeria. On many occasions, judicial officers have been said to have compromised in the discharge of their duties and yielded to corruption and partisanship (Onapajo and Uzodike 2014; Ojo 2011). There have been allegations of rigging through the court (Onapajo and Uzodike 2014; Abdullahi 2013). A foremost Nigerian lawyer, Robert Clarke (SAN), once said on Channels TV (Nigeria) that some politicians told him that it was not about what they would pay lawyers but what they would pay judges. It is so bothersome that the judiciary has been described as a place where elections are won and lost. For instance, Imo State Governor, Hope Uzodimma, is tagged Supreme-Court Governor because electorate in Imo State believe that he was not their preferred candidate at the election.

Just three weeks to the general elections, President Buhari suspended the Chief Justice of Nigeria, Walter Onnoghen, based on a report of an investigation which indicated that the Chief Justice failed to declared his assets as statutory required by law. It must be pointed out that the Supreme Court is the final arbiter of National Assembly, Governorship and Presidential election petition cases. The International Republican Institute (IRI) and National Democratic Institute (NDI) report that the suspension of the Chief Justice of Nigeria three to elections, raised doubts about the independence of the Supreme Court and the electoral tribunals (IRI/NDI 2019). Moreover, the president's constitutional authority to sack a sitting Chief Justice of the Federation without recourse to the National Assembly, painted the action as politically motivated in order to get a favorable litigation outcome as it eventually turned out to be. Some analyst opined that the suspension of Onnoghen was pave way for a more pliant Justice that may guarantee the president's prospects as post-election litigation were expected to run through to the Supreme Court. Prior to this matter, there were deluge of prophecies that Atiku Abubakar was going to win the presidential election. As shown in Table 1 above, Prophet Temitope Aduroja said he saw the defeat of the president and therefore urged the Buhari to accept defeat in due course. For Prophet Okechukwu, "God told me that any man that would want to stop Atiku from entering will go down and might not witness Atiku's celebration of victory." Prophet Emmanuel Stephen said he saw the Peoples Democratic Party, Atiku Abubakar walked to sit on a throne decorated with the country's colors, but someone removed the throne, making Atiku sit on the floor. Later, when the throne reappeared, it was President Buhari who sat on it. Popular Catholic Priest, Rev. Fr. Ejike Mbaka said as he was "waiting on the Lord, I'm asked to advise you (President Buhari), don't come out for second tenure; after this, retire peacefully."

\section{Conclusion and Recommendations}

This article has shed light on the phenomenon of prophecies in Nigeria's electoral process. The religious inclinations of many Nigerians make the phenomenon of political prophetic rife in the country's body politic. Spiritual modes have occupied crucial position in political activities and engagements in Nigeria. However, since the source of prophetic revelations is beyond empirical realm, it may be prone to manipulation and misinterpretation of reality. Hence, the article has tried to highlight possible threats inherent in such prophetic utterances. Even though the manifest intention of those prophecies may not be to destabilize the polity, the article argues that they may undermine state institutions involved in the electoral process.

It is therefore recommended that the umbrella bodies of faith-based organizations such as the Christian Association of Nigeria (CAN) and Pentecostal Fellowship of Nigeria (PFN) amongst others, should guide their members about the need to avoid releasing prophecies pertaining to 
politics and elections indiscriminately. While freedom of speech is guaranteed in the constitution, it should be not used in a way that threatens national security and cohesion. Religious and spiritual leaders - imams, pastors, etc.—-should be guided when they engage with political matters.

\section{REFERENCES}

Aalberg, Toril, and Aelst, Peter van. 2014. "Who is Afraid of Preelection Polls? How Perceptions of Polls Influence Support for Polling Regulations among Elites." International Journal of Public Opinion Research 26 (4): 517-530. https://doi.org/10.1093/ijpor/edt040.

Abati, Rueben. 2018. "2019: A Brief Manual of Nigerian Politics." Thisday, September 11, 2018. https://www.thisdaylive.com/index.php/2018/09/11/2019-a-brief-manual-ofnigerian-politics.

Abdullahi, Mukhtar. 2013. "Elections and Political Violence in Nigeria: Past Mistakes and Challenges Ahead." International Journal of Advanced Legal Studies and Governance 4 (1): 63-74.

Acheampong, Frederick. 2018. "Pentecostals and Politics in Ghana's Fourth Republic: From Enclave to Engagement." PhD diss., University of Wellington.

Adedigba, Azeezat, and Taiwo-Hassan Adebayo. 2019. "INEC Officials accuse Nigerian Army of disrupting elections in Rivers." Premium Times, February 26, 2019. https://www.premiumtimesng.com/regional/south-south-regional/316259-inecofficials-accuse-nigerian-army-of-disrupting-elections-in-rivers.html.

Adejumobi, Said. 2000. "Elections in Africa: A Fading Shadow of Democracy?" International Political Science Review 21 (1): 59-73. https://doi.org/10.1177\%2F0192512100211004.

Adeniyi, Gbenga, and Tope Omogbolagun. 2019. "Failed Prophecies on Buhari, Atiku Presidential Poll Contest." Punch, March 3, 2019. https://www.punchng.com/failedprophecies-on-buhari-atiku-presidential-poll-contest.

Adibe, Jideofor. 2015. "INEC and the Challenges of Free and Fair Elections in Nigeria." Accessed December 2, 2019. https://www.inecnigeria.org/wp-content/uploads/2019/02 /Conference-Paper-by-Jideofor-Adibe.pdf.

Adibe, Jideofor. 2018. "Predicting the 2019 Presidential Election." Cable, December 62018. https://www.thecable.ng/predicting-the-2019-presidential-election.

Akinkuotu, Eniola, and Adelani Adepegba. 2019. "Elections: PDP rejects Redeployment of 37 CPs, says it's Politically Tainted." Punch, February 7, 2019 https://punchng.com /elections-pdp-rejects-redeployment-of-37-cps-says-its-politically-tainted.

Alagbe, Jesusegun. 2020. "Gone with the Wind: 2019 Prophecies that were Wide of the Mark." Punch, January 5, 2020. https://punchng.com/gone-with-the-wind-2019-propheciesthat-were-wide-of-the-mark.

Arnesen, Sveinung, Mikael Johannesson, Jonas Linde, and Stefan Dahlberg. 2017. "Do Polls Influence Opinions? Testing the Spiral of Silence using a Dynamic Response Feedback Algorithm." Working Paper Series, University of Bergen. https://www.uib.no /sites/w3.uib.no/files/attachments/working_paper_2017-1.pdf.

Attoh, Franca. 2016. "Security and the 2015 Elections: Issues and Perspectives." Journal of Religion and Human Relations 8 (1): 97-116.

Ayantayo, K. Jacob. 2009. "Religious Factors in the Nigerian Public Sphere: Burdens and Prospects." Africa Development 34(3-4): 933-109. https://doi.org/10.4314/ad.v34i3-4.63530.

Burgess, Richard. 2015. "Pentecostalism and Democracy in Nigeria: Electoral Politics, Prophetic Practices, and Cultural Reformation." Nova Religio: The Journal of Alternative and Emergent Religions 18 (3): 38-62. https://doi.org/10.1525/nr.2015.18.3.38. 
Chinwo, Ernest. 2016. "Rerun Polls: APC Unleashes Full Weight of Federal Might on Rivers." Thisday, December 9, 2016. https:/www.thisdaylive.com/index.php/2016/12/09 /rerun-polls-apc-unleashes-full-weight-of-federal-might-on-rivers.

Dahlgaard, Jens Olav, Jonas Hedegaard Hansen, Kasper M. Hansen, and Martin V. Larsen. 2016. "How are Voters Influenced by Opinion Polls? The Effect of Polls on Voting Behaviour and Party Sympathy." World Political Science 12 (2): 283-300. https://doi.org/10.1515/wps-2016-0012.

Edewor, O. Dennis. 2008. "Prophetic and Pseudo-Active Contributions of Religious Entities to the Political Process in Nigeria." CODESRIA, 12th General Assembly "Governing the African Public Sphere." Yaounde, Cameroun. December 7-11, 2008.

Frankovic, Kathy, Timothy Johnson, and Marina Stavrakantonak. 2018. Freedom to Conduct Opinion Polls: A 2017 Worldwide Update. Amsterdam: ESOMAR/WAPOR.

Gyimah-Boadi, Emmanuel. 2015. “Africa's Waning Democratic Commitment." Journal of Democracy 26 (1): 101-113. https://doi.org/doi:10.1353/jod.2015.0000.

Gez, Yonatan N., and Droz, Yvan. 2015. "Negotiating and Erosion of Born Again Prestige in Nairobi." Nova Religio: The Journal of Alternative and Emergent Religions 18 (3): 18-37. https://doi.org/10.1525/nr.2015.18.3.18.

Hamalai, Ladi, Samuel Egwu, and J. Shola Omotola. 2017. Nigeria's 2015 General Election: Continuity and Change in Electoral Democracy. Switzerland: Palgrave Macmillan.

Heuser, Andreas. 2015. "Disjunction-Conjunction-Disillusionment: African Pentecostalism and Politics." Nova Religio: The Journal of Alternative and Emergent Religions 18 (3): 7-17. https://doi.org/10.1525/nr.2015.18.3.7.

Ibeanu, Okechukwu. n.d. "Party Ideology, Party Supremacy and Democratic Governance in Nigeria's 4th Republic: Some Reflections." A paper presented at the Savannah Centre for Diplomacy, Democracy and Development, Suite 3B and E, Adisa Plaza, Abdulsalami Abubakar Road, Opp. Ajuji Hotel, Gudu-Apo, Abuja, Nigeria. Accessed June 22, 2016.

Ikem, A. Patrick, N. Confidence Ogbonna, and Olusola Ogunnubi. 2020. "Pentecostalism, Electoral Prophetism and National Security Challenges in Nigeria." African Security 13 (1): 28-53. https://doi.org/10.1080/19392206.2020.1731111.

ICIR (International Center for Investigative Reporting) 2015. "Dasuki blew Millions to Employ Marabouts for Jonathan's Re-election.” December 4, 2015. https://www.icirnigeria.org /dasuki-blew-millions-to-employ-marabouts-for-jonathans-re-election.

International Republican Institute (IRI) and National Democratic Institute (NDI). 2019. Nigeria International Election Observation Mission Final Report. Washington, DC: IRI/NDI. https://www.ndi.org/sites/default/files/IRI-NigeriaElectionReport-Final.pdf.

Kwasi, Ansu-Kyeremeh. 1999. "The Challenges of Surveying Public Opinion in an Emerging Democracy." International Journal of Public Opinion Research 11 (1): 59-74.

Lewis-Beck, S. Michael. 2005. "Election Forecasting: Principles and Practice." British Journal of Politics and International Relations 7 (2): 145-164. https://doi.org/10.1111/j.1467-856X.2005.00178.x.

Lindberg, Staffan. 2006. "The Surprising Significance of African Elections." Journal of Democracy 17 (1): 139-151.

Makinde, Femi. 2018. "Osun Lawmaker's Nude goes Viral as Court Remands Alleged Blackmailers." Punch, September 17, 2018. https://punchng.com/osun-lawmakersnude-goes-viral-as-court-remands-alleged-blackmailers.

Marsh, Catherine. 1985. "Back on the Bandwagon: The Effect of Opinion Polls on Public Opinion.” British Journal of Political Science 15 (1): 51-74. https://doi.org/10.1017/S0007123400004063.

Morse, L. Yonatan. 2018. "Presidential Power and Democratization by Elections in Africa." Democratization 25 (4): 709-727. https://doi.org/10.1080/13510347.2017.1419188. 
Moy, Patricia, and Eike Mark Rinke. 2012. "Attitudinal and Behavioral Consequences of Published Opinion Polls." In Opinion Polls and the Media: Reflecting and Shaping Public Opinion, edited by Jesper Strömbäck and Christina Holtz-Bacha, 225-245. London: Palgrave Macmillan.

Ndujihe, Clifford. 2017. "Rivers Election Re-run: INEC Report Inducts Security Agencies." Vanguard, February 22, 2017. http://www.vanguardngr.com/2017/02/rivers-electionre-run-inec-report-indicts-security-agencies.

N'Guessan, Konstanze. 2015. "Cote d'Ivoire: Pentecostalism, Politics, and Performances of the Past." Nova Religio: The Journal of Alternative and Emergent Religions 18 (3): 80100. https://doi.org/10.1525/nr.2015.18.3.80.

Nwachukwu, J. Owen. 2020. "Prophet Olabayo Reveals what God told him about Edo Election, 2023 Presidency, says APC, PDP will Fizzle Out.” Daily Post, February 11, 2020. https://dailypost.ng/2020/02/11/prophet-olabayo-reveals-what-god-told-him-aboutedo-election-2023-presidency-says-apc-pdp-will-fizzle-out.

Nwodo, Anike. 2016. "Enugu Prophet Makes His Unbelievable Prediction 4 Years Ago." Legit, January 13, 2015. https:/www.legit.ng/359727-enugu-prophet-makes-hisunbelievable-prediction.html.

Nwolise, B. C. Osisioma. 2015. The Role of Prophets in Society Yesterday, Today and Tomorrow: Nigeria's 2015 General Elections in Perspective. Ibadan: Gold Press Limited.

Ojo, Emmanuel. 2011. "Public Perceptions of Judicial Decisions on Election Disputes: The Case of the 2007 General Election in Nigeria: Democratization in Nigeria." Journal of African Elections 10 (1): 101-113.

Olafioye, Olakunle. 2019. "Presidential Poll: The Clerics and their Prophecies." The Sun, March 3, 2019. https://www.sunnewsonline.com/presidential-poll-the-clerics-andtheir-prophecies.

Olowolagba, Fikayo. 2019. "Buhari vs Atiku: How TB Joshua, Mbaka, Iginla, other's Prophecies on 2019 Presidential election came to Pass." Daily Post, February 27, 2019. https://dailypost.ng/2019/02/27/buhari-vs-atiku-tb-joshua-mbaka-iginla-othersprophecies-2019-presidential-election-came-pass.

Omenma, Tochukwu. 2019. "Court Adjudications on Pre-Election Disputes in Young Democracies: The Impact on Electoral Management Body in Nigeria, 1999-2011." International Journal of Euro-Mediterranean Studies 12 (1): 93-134.

Omotola, J. Shola. 2009. "Nigerian Parties and Political Ideology." Journal of Alternative Perspectives in the Social Sciences 1 (3): 612-634.

Omotola, J. Shola. 2010. "Elections and Democratic Transition in Nigeria under the Fourth Republic.” African $\quad$ Affairs $109 \quad$ (437): https://doi.org/https://doi.org/10.1093/afraf/adq040.

Onapajo, Hakeem, and O. Nwabufo Uzodike. 2014. "Rigging through the Courts: The Judiciary and Electoral Fraud in Nigeria." Journal of African Elections 13 (2): 137-168. https://doi.org/10.20940/JAE/2014/v13i2a7.

Onapajo, Hakeem. 2012. "Politics for God: Religion, Politics and Conflict in Democratic Nigeria." Journal of Pan African Studies 4 (9): 42-66.

Onapajo, Hakeem. 2015. "How Credible were the Nigerian 2015 General Elections? 'An Electoral Integrity' Framework of Analysis." African Renaissance 12 (3-4): 11-39.

Onyeji, Ebuka. 2018. "Father Mbaka turns against Buhari, warns against Re-election Bid." Premium Times, January 2, 2018. https://www.premiumtimesng.com/news/headlines /254219-father-mbaka-turns-buhari-warns-re-election-bid.html.

Osaghae, E. Eghosa. 1999. "Exiting from the State in Nigeria." African Journal of Political Science 4 (1): 83-98. 
Posner, N. Daniel, and J. Daniel Young. 2008. "The Institutionalization of Political Power in Africa." Journal of Democracy 18 (3): 126-140.

Saliu, Hassan, and I. Solomon Ifejika. 2017. "The Missing Rib of Nigeria's Democracy." South East Journal of Political Science 3 (1): 250-284.

Schmitt-Beck, Rudiger. 1996. "Mass Media, the Electorate, and the Bandwagon: A Study of Communication Effects on Vote Choice in Germany." International Journal of Public Opinion Research 8 (3): 266-291. https://doi.org/10.1093/ijpor/8.3.266.

Sobechi, Leo. 2016. "Why Polls Do Not Count Anymore." Guardian (Nigeria), November 20, 2016. https://guardian.ng/features/policy-a-politics/why-polls-do-not-count-anymore.

Stolwijk, Sjoerd, Andreas R. T. Schuck, and Claes H. de Vreese. 2017. "How Anxiety and Enthusiasm Help Explain the Bandwagon Effect." International Journal of Public Opinion Research 29 (4): 554-574. https://doi.org/10.1093/ijpor/edw018.

The Nation. 2018. "Guru to Buhari: Come to me to win 2019 Election." November 3, 2018. https://thenationonlineng.net/guru-to-buhari-come-to-me-to-win-2019-election.

The Nation. 2019. "Seers who Goofed." March 2, 2019. https://thenationonlineng.net/seerswho-goofed.

Tukur, Sani. 2014. "2015 Election: Buhari Leads Jonathan in Poll Organized by Presidential Aide." Sahara Reporters, October 18, 2014. http://saharareporters.com/2014 /10/18/2015-election-buhari-leads-jonathan-poll-organized-presidential-aide.

Ujumadu, Vincent. 2015. "Okija Shrine: No Longer a Bee-hive of Activities for Politicians." The Vanguard, August 25, 2015. https://www.vanguardngr.com/2015/08/okija-shrineno-longer-a-bee-hive-of-activities-for-politicians.

Wallace, Paul. 2019. "Buhari vs. Abubakar: Who Analysts See Winning Nigeria's Vote." Bloomberg, February 15, 2019. https://www.bloomberg.com/news/articles/2019-0215/buhari-versus-abubakar-who-analysts-see-winning-nigeria-s-vote.

Rothschild, David and Justin Wolfers, Justin. 2012. "Forecasting Elections: Voters Intentions versus Expectations." November 1, 2012. https://www.brookings.edu/wpcontent/uploads/2016/06/01-voter-expectations-wolfers.pdf.

Whistler. 2017. "Pastor Tunde Bakare: Hits, misses of His prophecies." June 22, 2017. https://thewhistler.ng/story/pastor-tunde-bakare-hits-misses-of-his-prophecies.

Yahaya, Halimah. 2019. "INEC Server shows Buhari lost Presidential Election with 1.6 million votes, Atiku, PDP Claim." Premium Times, March 20, 2019. https://www.premiumtimesng.com/news/headlines/321177-inec-server-shows-buharilost-presidential-election-with-1-6-million-votes-atiku-pdp-claim.html.

Yong, Amos. 2014. "Pentecostalism, Politics, and the Prophetic: Renewing the Public Square 11." Reverberations: New Directions in the Study of Prayer, January 21, 2014. http://forums.ssrc.org/ndsp/2014/01/21/pentecostalism-politics-and-the-propheticrenewing-the-public-square-ii.

\section{ABOUT THE AUTHORS}

Patrick Afamefune Ikem: PhD Student, Department of Political Science, University of Nigeria, Nsukka, Nigeria

Abiodun Omotayo Oladejo, PhD: Researcher, Institute of Social and Health Sciences, University of South Africa, Pretoria, Gauteng, South Africa

Kingsley Chigozie Udegbunam, PhD: Lecturer, Peace and Conflict Resolution Unit, School of General Studies, University of Nigeria, Nsukka, Nigeria 


\section{The International Journal of Religion and}

Spirituality in Society aims to create an intellectual frame of reference for the academic study of religion and spirituality and to create an interdisciplinary conversation on the role of religion and spirituality in society. It is intended as a place for critical engagement, examination, and experimentation of ideas that connect religious philosophies to their contexts throughout history in the world, places of worship, on the streets, and in communities. The journal addresses the need for critical discussion on religious issues-specifically as they are situated in the present-day contexts of ethics, warfare, politics, anthropology, sociology, education, leadership, artistic engagement, and the dissonance or resonance between religious tradition and modern trends.
Articles published in the journal range from the expansive and philosophical to finely grained analysis based on deep familiarity and understanding of a particular area of religious knowledge. They bring into dialogue philosophers, theologians, policymakers, and educators, to name a few of the stakeholders in this conversation.

The International Journal of Religion and Spirituality in Society is a peer-reviewed, scholarly journal. 